\title{
Behavioral and Neurochemical Responses to Cocaine in Periadolescent and Adult Rats
}

\author{
Kyle J Frantz ${ }^{*, 1}$, Laura E O'Dell ${ }^{2}$ and Loren H Parsons ${ }^{3}$ \\ 'Department of Biology, Georgia State University, Atlanta, GA, USA; ²Department of Psychology, The University of Texas at El Paso, El Paso, TX, \\ USA; ${ }^{3}$ Molecular and Integrative Neurosciences Department, The Scripps Research Institute, La Jolla, CA, USA
}

\begin{abstract}
Although recreational drug use by human adolescents is a well-known and long-standing problem, relatively little is known regarding differences in behavioral and physiological responses to abused substances in adolescent vs adult animals. The present study compared effects of the psychomotor stimulant, cocaine, in periadolescent (postnatal days 37-52) and adult (postnatal days 75-90) male Wistar rats. Locomotion and motor stereotypy were recorded after acute and repeated cocaine injections $(0,10$, or $20 \mathrm{mg} / \mathrm{kg}$ cocaine, intraperitoneal (i.p.), four injections spaced 5 days apart). Spontaneous acquisition of intravenous (i.v.) cocaine self-administration was investigated in two dose groups ( $\sim 0.37$ or $0.74 \mathrm{mg} / \mathrm{kg} /$ infusion) over 14 days. Dopamine levels in the nucleus accumbens were recorded under basal conditions (no net flux method) and after cocaine administration ( $\sim 0.37,0.74$, and $2.92 \mathrm{mg} / \mathrm{kg} / \mathrm{i} . \mathrm{v}$. infusion or $20 \mathrm{mg} / \mathrm{kg}$ i.p.) using in vivo microdialysis. The locomotor data are in partial agreement with previous reports of hyposensitivity to acute cocaine in periadolescent vs adult rats; periadolescents were less active overall than adults. Moreover, adult rats exhibited significant locomotor sensitization after repeated injection of $10 \mathrm{mg} / \mathrm{kg}$ cocaine, whereas periadolescents required the high dose of $20 \mathrm{mg} / \mathrm{kg}$ cocaine to demonstrate sensitization. Neither age group showed sensitization of motor stereotypies. No age-related difference was observed in acquisition of cocaine self-administration, or in basal or cocaine-stimulated nucleus accumbens dopamine. These experiments imply a developmental dissociation between the motor activating and reinforcing effects of cocaine. Similarities in dopamine levels across age groups suggest that age-specific motor responses to cocaine are not mediated by dopamine in the nucleus accumbens. Neuropsychopharmacology (2007) 32, 625-637. doi: I 0. I038/sj.npp. I 30 I I 30; published online 21 June 2006
\end{abstract}

Keywords: motor activity; intravenous self-administration; in vivo microdialysis; nucleus accumbens; dopamine; adolescent

\section{INTRODUCTION}

Almost 1.5 million Americans abuse cocaine (SAMHSA, 2003). Most cocaine users are adolescents or had their first contact with cocaine during adolescence (Johanson and Fischman, 1989; SAMHSA, 2003). In fact, early exposure to drugs of abuse might be a strong predictor of later drug use and dependence (Johanson and Fischman, 1989; Kandel and Davies, 1992). Cocaine use among adolescents typically involves rapid escalation to high levels of intake (Estroff et al, 1989), perhaps related to reportedly less intense euphoric and stimulatory effects of the drug in young cocaine users compared with adults (Koob et al, 1994). Nevertheless, laboratory investigations have yet to determine whether or not these trends reflect developmental changes in the physiological effects of cocaine. The present study aimed to compare behavioral and neurochemical effects of cocaine in adolescent $v s$ adult rodents.

\footnotetext{
*Correspondence: Dr KJ Frantz, Department of Biology, Georgia State University, PO Box 40 I0, Atlanta, GA 30302-40I0, USA, Tel: + I 404 65 I |487, Fax: + | 40465 I 3929, E-mail: kfrantz@gsu.edu

Received 3 May 2005; revised I March 2006; accepted I March 2006 Online publication: 23 May 2006 at http:/www.acnp.org/citations/ Npp052306050288/default.pdf
}

Whereas adolescence in humans and non-human primates extends over several years, rodent models of this developmental stage, termed 'periadolescence,' are limited to the 2 weeks between approximately 35 and 50 days of age (postnatal days (PND) 35-50; Spear and Brake, 1983; Spear, 2000). Other estimates of rodent adolescence shift earlier by a week or so, such as PND 28-42 (Collins and Izenwasser, 2004; Maldonado and Kirstein, 2005a, b). In many species including rodents, this transition from youth to adulthood entails physiological maturations such as gonadarche and adrenarche, as well as ethological factors such as departing from the early postnatal home environment and changing social companions from immediate family members to other age-mates (Campbell et al, 2000, for review).

Several behavioral characteristics are common in both rodent and primate periadolescence. Examples include a high amount of time spent in social interaction and play behavior (Brown, 1990; Panskepp, 1981), high levels of risktaking, sensation-seeking, or novelty-seeking (Adriani et al, 1998; Zuckerman, 1992), and general hyperactivity or hyperexploration of a novel environment (Bronstein, 1972, 1979; Caza and Spear, 1980; but see Bauer and Duncan, 1975; Frantz and Van Hartesveldt, 1999). Mesocorticolimbic dopamine circuitry is integral to these behaviors (Bardo, 
1998; Burns et al, 1996; Critchley et al, 2000; Hooks et al, 1994; Russell, 2000) and is also implicated in the motoractivating and reinforcing effects of stimulants (Koob, 1992; Wise and Bozarth, 1987). This system and related inputs continue to mature throughout periadolescence (Campbell et al, 2000, for review). For instance, during the periadolescent period or just prior, dopamine receptors are transiently overexpressed in striatal regions (Gelbard et al, 1989; Seeman et al, 1987; Tarazi et al, 1998, 1999, 1995), levels of basal or receptor-stimulated second messenger activities fluctuate (Andersen, 2002), voltammetric measures of dopamine release and uptake remain lower than in adults (Stamford, 1989), and dopaminergic innervation of the prefrontal cortex increases (Kalsbeek et al, 1988). Such reorganization of behavior and neural circuitry may underlie developmental alterations in responsiveness to a variety of agents including cocaine. Coupled with data on human drug use during adolescence, these findings have led to the hypothesis that periadolescence is a period of heightened vulnerability to the addictive properties of cocaine and other drugs (Campbell et al, 2000; Laviola et al, 1999).

For several decades, most reports indicated that periadolescent rats are less responsive than younger or older rats to psychomotor stimulants. Periadolescent Sprague-Dawley and Long Evans rats ranging from PND 28 to 45 were less sensitive to motor activation induced by several indirect or mixed dopamine agonists including cocaine, amphetamine, and apomorphine (Bolanos et al, 1998; Lanier and Isaacson, 1977; Laviola et al, 1995; Shalaby and Spear, 1980; Snyder et al, 1998; Spear and Brake, 1983). After repeated, intermittent injection of cocaine, periadolescent rats (PND 35-45) also exhibited similar or a lower degree of sensitization of cocaine-induced locomotion compared with weanlings (PND 21-27) or adults (Collins and Izenwasser, 2002; Laviola et al, 1995; Snyder et al, 1998) as well as a similar low level or lower degree of sensitization of some cocaine-induced motor stereotypies (Laviola et al, 1995; Snyder et $a l, 1998)$. In terms of neuroendocrine effects, plasma corticosterone responses were lower in PND 35-38 rats after acute or repeated cocaine injections compared with PND 60-70 adults (Laviola et al, 1995), and also in PND 33-43 vs > PND 70 mice after acute amphetamine (Adriani and Laviola, 2000). During classical conditioning, PND 35 rats were resistant to taste aversions conditioned by amphetamine injection, whereas juvenile (PND 18) and young adult (PND 52) rats displayed strong aversions (Infurna and Spear, 1979).

However, not all studies point to a periadolescent hyposensitivity to psychostimulants. A recent study revealed similar locomotor activation by cocaine in PND $45 v s$ 60 rats (Maldonado and Kirstein, 2005a, b), although handling procedures or the later adolescent/earlier adult ages of testing may have contributed to this result. During operant conditioning, PND 27, 37, and 90 rats did not differ significantly in their rates of nose-poking behavior reinforced by intravenous (i.v.) cocaine infusions (Belluzzi et al, 2005). In terms of stimulant-related reward, PND 3437 and $65-78$ adult rats displayed the same preference for a cocaine-paired environment in a conditioned place preference paradigm, and PND 30-49 mice displayed no preference for an amphetamine-paired environment (Adria- ni and Laviola, 2003; Campbell et al, 2000; but see Laviola et al, 1994).

Some recent experiments even demonstrate adolescents to be more sensitive than adults to stimulants. A sensitization study in CD-1 outbred mice revealed significant locomotor sensitization after repeated amphetamine injection in PND 33-43 mice but not their adult ( $>$ PND 60) counterparts (Adriani et al, 1998). Adolescents may also be more sensitive than their adult counterparts to nicotine (Adriani et al, 2004, 2002; Elliott et al, 2005; Faraday et al, 2003; Vastola et al, 2002; but see Schochet et al, 2004). In an operant behavior paradigm, PND 27 male rats acquired stable nose-poking behavior maintained by a combination of nicotine and components of tobacco smoke faster than PND 90 adults, and self-administered more of the drug combination (Belluzzi et al, 2005). A trend toward higher nicotine self-administration among late adolescent/young adult (PND 54-62) female rats compared with older adult females ( $>$ PND 90) was also reported (Levin et al, 2003). In terms of neurochemistry, PND 33-43 male rats demonstrated neurochemical sensitization after repeated amphetamine injection when their adult ( $>$ PND 70) counterparts did not (Laviola et al, 2001). Similarly, Bolanos et al (1998) reported neurochemical supersensitivity in acetylcholinergic response to dopamine agonists at PND 35, compared with adults (age not specified). Thus, generalizations cannot be made regarding differential sensitivity among periadolescent and adult subjects with regard to the behavioral and neurochemical effects of psychomotor stimulant drugs.

The present study directly compared the motor stimulant and reinforcing effects of cocaine in periadolescent $v s$ adult male Wistar rats. The first experiment aimed to re-evaluate the motor response to cocaine in periadolescents (PND 3739 at start) $v s$ adults (PND 73-75 at start) using a different rat strain and longer time interval between injections than previous studies (Bolanos et al, 1998; Collins and Izenwasser, 2002, 2004; Laviola et al, 1995; Snyder et al, 1998). This experiment provided a context in which to analyze cocainerelated behavioral reinforcement via i.v. cocaine selfadministration using a lever-pressing paradigm and a longer acquisition period than previously utilized (Belluzzi et al, 2005). Because the locomotor stimulant and reinforcing effects of cocaine are mediated in part by dopamine in the nucleus accumbens (Koob, 1992; Wise, 1996; Wise and Bozarth, 1987), the final experiment investigated nucleus accumbens dopamine levels in both age groups using in vivo microdialysis. Basal extracellular levels of dopamine were estimated by calculating the concentration at which no net exchange of analyte occurred across the dialysis membrane (ie no net flux; Lonnroth et al, 1987). Dopaminergic responses to i.v. or intraperitoneal (i.p.) cocaine injection were also compared, and dialysate levels of cocaine were assessed for potential age-related differences in cocaine bioavailability or clearance.

\section{MATERIALS AND METHODS}

\section{Subjects}

Male Wistar rats (Charles River Laboratories, Wilmington, MA) arrived at postnatal day (PND) $21-23$ or $60-62$ and 
were housed in groups of $2-3$ in a humidity- and temperature-controlled $\left(22^{\circ} \mathrm{C}\right)$ vivarium on a $12 \mathrm{~h}$ light/ dark cycle. Lights came on at 0600 hours for i.p. injection experiments and data were collected in the light. Lights went off at 1000 hours for i.v. injection experiments and data were collected in the dark. (Phases were based on relevant studies.) Rats acclimated for 5-7 days before experiments and had ad libitum access to food and water throughout experimentation. Subjects were observed and/or weighed daily to assess health and drug responsiveness. All procedures adhered to the 'Principles of Laboratory Animal Care' and the National Institutes of Health Guide for the Care and Use of Laboratory Animals.

\section{Drugs}

Cocaine $\mathrm{HCl}$ was obtained from the National Institute on Drug Abuse (Washington, DC, USA). Methohexital sodium (1\%, Brevital Sodium) was from Eli Lilly (Indianapolis, IN). All chemicals for artificial cerebrospinal fluid (aCSF), HPLC mobile phase, and chromatographic standards were from Sigma Chemicals (St Louis, MO), except acetonitrile from VWR Pharmaceuticals (San Francisco, CA) and EDTA from JT Baker Chemical Co. (Phillipsburg, NJ).

\section{Experiment I: Effects of Acute and Repeated Cocaine Injection on Motor Activity}

Motor activity was measured in $23 \times 46 \mathrm{~cm}$ plastic cages either 20 or $28 \mathrm{~cm}$ high for periadolescent or adult rats, respectively, located in a room separate from the vivarium. Each cage was surrounded by two sets of photocell beams (San Diego Instruments, La Jolla, CA): a low set positioned $4 \mathrm{~cm}$ above the floor and a high set positioned 12 or $17 \mathrm{~cm}$ above the floor for periadolescents or adults, respectively. Each low set contained eight photocells spaced evenly along the long axis and four photocells along the short axis. Each high set had eight photocells on the short axis. Photocellbeam interruptions were recorded in 5 -min bins by a DOSbased computer system. 'Matrix crossings' were calculated from beam interruptions in each octant.

Animals were handled and weighed daily for 3-5 days before the first test at PND 37-39 or 73-75, and were acclimated to the testing room for $15 \mathrm{~min}$ ( $n=6-10$ per group). Sessions began when rats were placed individually in a test cage for a 30 -min habituation period. Subsequently, each rat was removed, injected with cocaine $(10$ or $20 \mathrm{mg}$ / $\mathrm{kg}$, i.p.) or saline vehicle $(1 \mathrm{ml} / \mathrm{kg})$, and returned for $120 \mathrm{~min}$. Testing was conducted during the light phase to facilitate observation of motor activity and to replicate previous experiments (Bolanos et al, 1998; Infurna and Spear, 1979; Laviola et al, 1995; Snyder et al, 1998).

Stereotyped behaviors (sniffing, rearing, grooming, headbobbing, and oral stereotypy) were scored during habituation and for $60 \mathrm{~min}$ after injection. Experimenters rated each rat every $10 \mathrm{~s}$ for a total of six possible scores per min, or 180 possible scores per $30 \mathrm{~min}$ (O'Dell et al, 1996). 'Lying Still' was recorded in the absence of stereotypy or locomotion.

To assess age differences in repeated intermittent effects of cocaine, all subjects underwent the same procedure 5, 10, and 15 days later, receiving the same dose on all 4 days but no injections between test days. Injections were always given in the testing environment. Automated measures were taken on all days, but experimenter ratings were conducted only on the first and last days.

\section{Experiment II: Acquisition of Cocaine Self-Administration}

Equipment. The i.v. catheters used for self-administration were constructed as described (Caine et al, 1993), with minor modifications (Emmett-Oglesby and Lane, 1992). Alterations in catheters for periadolescents included a shorter length of silastic tubing inserted into the vein $(2.0$ $v s 3.5 \mathrm{~cm}$ ) because the distance from vein incision to the atrium of the heart was shorter in smaller immature rats. Also a cotton mesh 'back plate' was used instead of plastic mesh because the dermal tissue of developing rats may have been subject to tearing by hard plastic. Self-administration chambers consisted of operant boxes enclosed in soundattenuating, ventilated environmental cubicles (MED Associates Inc., St Albans, VT or BRS/LVE, Laurel, MD). Two levers extended into the chamber to start each session. Pressing on the 'active lever' initiated a syringe pump with a 5 r.p.m. motor (Model A; Razel Scientific Instruments, Stanford, CT) for $4 \mathrm{~s}$ to deliver $0.1 \mathrm{ml}$ drug solution via a stainless steel liquid swivel and polyethylene tube attached to the catheter on the animal's back. Each reinforced response lit a cue light above the lever, which stayed on throughout a 20-s time out (TO) period. Lever-presses during TO were recorded but not reinforced. Pressing on the 'inactive lever' was also recorded but not reinforced. Drug delivery and data collection were controlled by a DOSbased computer system.

Surgical procedures. At PND 29-31 for periadolescents or PND 67-69 for adults (mean body weight: $126.6, n=21$ or $302.8 \mathrm{~g}, n=21$, respectively), rats were implanted with i.v. catheters (Caine et al, 1993). Briefly, rats were anesthetized with a $1-2 \%$ halothane/oxygen vapor and catheter tubing was passed subcutaneously from the back to the right jugular vein, inserted into the vein previously punctured with a 25-gauge needle, and tied gently with suture thread. During recovery, periadolescent and adult rats received 0.1 or $0.2 \mathrm{ml}$, respectively, of the antibiotic ticarcillin $(100 \mathrm{mg} /$ ml, i.v.) twice daily for 2 days post-surgery, then once daily during testing. Catheters were also flushed daily with heparinized saline (30 USP units/ml).

Self-administration testing. Following a 7- to 9-day postsurgical recovery, spontaneous acquisition of cocaine selfadministration began (PND 38 or 76). Two-hour sessions were conducted daily for 14 days during the dark phase. (Dark phase testing maximized the likelihood rats would encounter the cocaine-associated lever.) Non-contingent injections were never administered. Lever pressing on the active lever was reinforced by i.v. injection of cocaine $\mathrm{HCl}$ under a fixed-ratio 1 TO20 sec schedule of reinforcement in dose groups receiving either $\sim 0.37$ or $\sim 0.74 \mathrm{mg} / \mathrm{kg} /$ infusion. (These doses approximated 0.125 or $0.25 \mathrm{mg}$ / infusion in previous experiments from this laboratory in which drug solutions were not titrated for body weight.) To account for differences in body weight between age groups, 
the concentration of cocaine solution for periadolescent rats was titrated on days 1 and 8 to match the mean adult dose in $\mathrm{mg} / \mathrm{kg} /$ infusion.

Patency of the i.v. catheters was tested 1 day before the first and immediately after the last test session by administering an ultra-short-acting barbiturate anesthetic (Brevital Sodium, 1\% methohexital sodium; Eli Lily, Indianapolis, IN) through the catheter. If muscle tone was not lost within $3 \mathrm{~s}$, the catheter was presumed defective and the subject was not included in analyses.

\section{Experiment III: Basal and Cocaine-Stimulated Dopamine Levels in the Nucleus Accumbens}

Apparatus. Microdialysis probes were constructed according to a procedure modified from Parsons et al (1991). Briefly, a $300 \mu \mathrm{m}$ o.d. regenerated cellulose dialysis membrane (13000 molecular weight cutoff; Spectrum Laboratories Inc., Laguna Beach, CA) was fitted over two lines of silica tubing $(40 \mu \mathrm{m}$ i.d., $105 \mu \mathrm{m}$ o.d., Polymicro Technology, Phoenix, AZ) held in an aluminum shaft. The membrane was sealed to the silica using fast-drying epoxy for an active membrane length of $2 \mathrm{~mm}$.

Dopamine was separated from $5 \mu$ l dialysate volumes injected onto a microbore HPLC system with a $1 \times 100 \mathrm{~mm}$ column $(3 \mu \mathrm{m}$ packing material, C18 stationary phase; Keystone, Bellefonte, PA). Mobile phase was composed of a $50 \mathrm{mM} \mathrm{NaH} \mathrm{PO}_{4}$ (monohydrate) buffer ( $\mathrm{pH}$ 3.92) with $17 \%$ acetonitrile, $0.27 \mathrm{mM} \mathrm{Na}_{2}$-EDTA, $0.4 \%$ triethylamine, and $3.27 \mathrm{mM}$ decane sulfonic acid, and was pumped at $35 \mu \mathrm{l} /$ min. An amperometric detector (EG\&G PARC Model 400, Princeton, NJ) using dual glassy carbon working electrodes was set at 700 and $-10 \mathrm{mV}$ against a $\mathrm{Ag} / \mathrm{AgCl}$ reference electrode (BAS, West Lafayette, IN). Dopamine concentrations were determined with an external calibration curve. Standard solutions contained $0.25 \mathrm{mM}$ ascorbic acid to minimize analyte auto-oxidation.

Cocaine was separated from $3 \mu \mathrm{l}$ volumes of dialysate injected onto an HPLC system equipped with a $1 \times 100 \mathrm{~mm}$ column $(3 \mu \mathrm{m}$ packing material, C18 stationary phase; Sepstix, BAS, West Lafayette, IN). Mobile phase was composed of a $48 \mathrm{mM} \mathrm{NaH} \mathrm{PO}_{4}$ (monohydrate) buffer ( $\mathrm{pH}$ 6.0) with $14 \%$ acetonitrile, $12 \%$ methanol, and $1.0 \%$ triethylamine and pumped at $30 \mu \mathrm{l} / \mathrm{min}$. A Spectra Physics Spectra Focus scanning multiple-wavelength ultraviolet detector was set with a flow cell absorption pathlength of $3 \mathrm{~mm}$, total cell volume of $1.2 \mu \mathrm{l}$, and absorbance wavelength of $225 \mathrm{~nm}$. Cocaine concentrations were determined using an external calibration curve.

Surgical procedures. Two different routes of cocaine administration (i.v. and i.p.) were tested in separate groups ( $n=5-10$ per age group). For i.v. cocaine injections, rats were surgically implanted with i.v. catheters at PND 30-33 or 70-74 as described above and were allowed 5-7 days recovery. For both i.v. and i.p. cocaine injection groups, microdialysis probes were implanted 1 day before testing. Thus, rats were anesthetized (1-2\% halothane or isofluorane vapor) and placed in a stereotaxic instrument at PND $38-40$ or 70-72 (i.p. group) and PND 37-40 or 77-80 (i.v. group). Microdialysis probes were implanted into the nucleus accumbens at coordinates of $\mathrm{AP}+1.7, \mathrm{ML} \pm 1.2$,
DV -7.9 or -8.1 , for periadolescent or adult rats, respectively, with measurements from dura and flat skull. Probes were secured to the skull with methylmethacrylate over skull screws (Small Parts Inc., Miami Lakes, FL). Animals were allowed $6-12 \mathrm{~h}$ recovery in the dialysis sampling environment $(23 \times 46 \times 28 \mathrm{~cm}$ plastic cages $)$ while the probes were perfused with aCSF at $0.2 \mu \mathrm{l} / \mathrm{min}$. For the i.v. administration group, microdialysis sampling consisted of two segments (described below) under low illumination during the dark phase. For the i.p. administration group, sampling consisted of just one segment (described below) under fluorescent light in the light phase. Different phases of the light/dark cycle matched the behavioral analyses of cocaine self-administration (dark phase i.v. administration) and motor activation (light phase i.p. administration).

Estimation of basal dopamine levels in the nucleus accumbens. The no net flux method was used to estimate extracellular levels of dopamine. Thus, concentrations of dopamine above and below the anticipated extracellular concentration in the nucleus accumbens were perfused through the probe. Resultant dialysate concentrations were compared to the perfusate concentrations to generate a series of points interpolated to determine the concentration at which there was no net analyte flux (Lonnroth et al, 1987; Parsons and Justice, 1992). Specifically, the perfusate flow rate was increased to $0.6 \mu \mathrm{l} / \mathrm{min} 1 \mathrm{~h}$ before dialysate sampling. Then, baseline samples were collected at $15-\mathrm{min}$ intervals for $1 \mathrm{~h}$. The perfusate was then changed to an aCSF containing dopamine $(2.5,5.0$, or $10 \mathrm{nM})$, allowed to equilibrate for $15 \mathrm{~min}$, then samples were collected for another $1 \mathrm{~h}$ before the perfusate was changed to a different concentration of dopamine. Dopamine concentrations were presented in varied order with all subjects receiving all concentrations.

Dopamine levels in the nucleus accumbens following i.v. cocaine injection. Cocaine injections were given i.v. in order to measure cocaine-related increases in extracellular dopamine in the nucleus accumbens. After the no net flux analysis, the flow rate was increased to $1.0 \mu \mathrm{l} / \mathrm{min}$ to facilitate sample separation for dopamine and cocaine quantitation in the dialysate. Following $1 \mathrm{~h}$ equilibration, baseline samples were collected at 10-min intervals for $60 \mathrm{~min}$, then three i.v. infusions of cocaine were given in succession $(\sim 0.37,0.74$, or $2.92 \mathrm{mg} / \mathrm{kg})$ each followed by $60 \mathrm{~min}$ of dialysate sampling, except the last infusion followed by $90 \mathrm{~min}$ sampling. Concentrations of cocaine were titrated across age groups to account for body weight. Injection volume determined dose within age groups. Thus, solutions of approximately 1.00 or $2.50 \mathrm{mg} / \mathrm{ml}$ for periadolescent or adult rats, respectively, were administered over 2, 4, or $16 \mathrm{~s}$ (Harvard Apparatus pump, South Natuck, MA).

Dopamine levels in the nucleus accumbens following i.p. cocaine injection. The perfusate flow rate was increased to $1.0 \mu \mathrm{l} / \mathrm{min}$ after recovery from probe implantation. Sixty minutes later, six baseline samples were collected at 10-min intervals. Rats were then briefly removed, injected with $20 \mathrm{mg} / \mathrm{kg}$ cocaine i.p., and returned immediately to the test cage to continue sampling for $2 \mathrm{~h}$. 


\section{Data Analysis and Histology}

Motor activity. Automated measures of acute cocaine-induced locomotion (matrix crossings) were analyzed using three-way analyses of variance (ANOVAs) with factors of age $\times$ cocaine dose $\times$ time. (Time was a repeated measure tested in $5 \mathrm{~min}$ blocks over the first $1 \mathrm{~h}$ of testing and in two $1 / 2 \mathrm{~h}$ intervals of 0-30 min and 30-60 min post-injection.) Matrix crossings after repeated cocaine were summed over the $2 \mathrm{~h}$ test and analyzed using a three-way ANOVA with main factors of age $\times$ cocaine dose $\times$ day. (Day was a repeated measure for days $0,5,10$, and 15). Two-way and one-way ANOVAs followed by post hoc analyses (simple effects or $t$-tests with Bonferroni's correction) were conducted as appropriate. In all cases, $p$-values $<0.05$ were considered significant. Observational measures of sniffing, grooming, and rearing were summed over the $1 \mathrm{~h}$ observation period and analyzed as above.

Self-administration data. Rats were defined as having acquired self-administration when their lever-pressing behavior met the following criteria for at least three successive sessions and throughout the remainder of the acquisition period: (a) the number of responses on the active lever exceeded two times the number of presses on the inactive lever and (b) the number of responses on the active lever was greater than 12. (Twelve is the average number of non-reinforced lever-presses made by cocaine-naïve periadolescent and adult rats in the absence of cocaine; data not shown.) See Donny et al (1998) for a similar definition of acquisition. The proportion of rats in each age group that acquired self-administration was compared for each test day using Fisher's exact test. Lever pressing on active and inactive levers was also compared using a three-way ANOVA on lever $\times$ age $\times$ days (repeated measure) for all rats. Finally, total cocaine intake $(\mathrm{mg} / \mathrm{kg}$ ) was compared among all rats using unpaired $t$-tests between age groups.

Microdialysis sampling. For the no net flux analysis, dialysate dopamine concentrations were estimated using the mean of four samples at each perfusate dopamine concentration $(0,2.5,5.0$, and $10.0 \mathrm{nM})$. First-order regressions provided the slope and intercept values to calculate the point of no net flux (zero intercept on the $y$-axis), which estimates extracellular dopamine concentration (Parsons and Justice, 1992). The in vivo probe recovery was calculated as the slope of the no net flux regression line. Values were compared using unpaired $t$-tests between age groups. For cocaine-stimulated dopamine, concentrations before cocaine injections did not differ between age groups, so percentage of baseline data were analyzed using two-way ANOVAs on age $\times$ time (repeated measure) and simple effects post hoc analyses as appropriate. Separate analyses were carried out for i.p. and i.v. routes of administration. Brain levels of cocaine (nM) were also analyzed with twoway repeated measures ANOVA and simple effects testing. Concentrations were not adjusted for probe efficiency.

Histology. Probe placement was verified by mounting $40 \mu \mathrm{m}$ brain slices, staining with cresyl violet, and examining under a microscope. Only those subjects with placement in the core/shell region medial to the anterior commissure between 1.00 and $2.70 \mathrm{~mm}$ anterior to bregma were included. Distinctions between core and shell were not investigated, but probe placements were more in the core than the shell in $60 \%$ of periadolescent subjects and $81 \%$ of adults, with remaining placements more in the shell.

\section{RESULTS}

\section{Experiment I: Effects of Acute and Repeated Cocaine Injection on Motor Activity}

Locomotor behavior. Periadolescent and adult rats demonstrated similar patterns of locomotor response to acute cocaine injection (Figure 1a-c). Matrix crossings increased dose-dependently after 10 or $20 \mathrm{mg} / \mathrm{kg}$ cocaine injections for 30 or $60 \mathrm{~min}$, respectively, regardless of age group. Adult rats exhibited more matrix crossings during the second 30 min post-cocaine interval, regardless of drug dose, but variability within age groups obscured overall interactions between age, dose, and time effects. Thus, three-way ANOVA on the first $30 \mathrm{~min}$ post-cocaine revealed significant

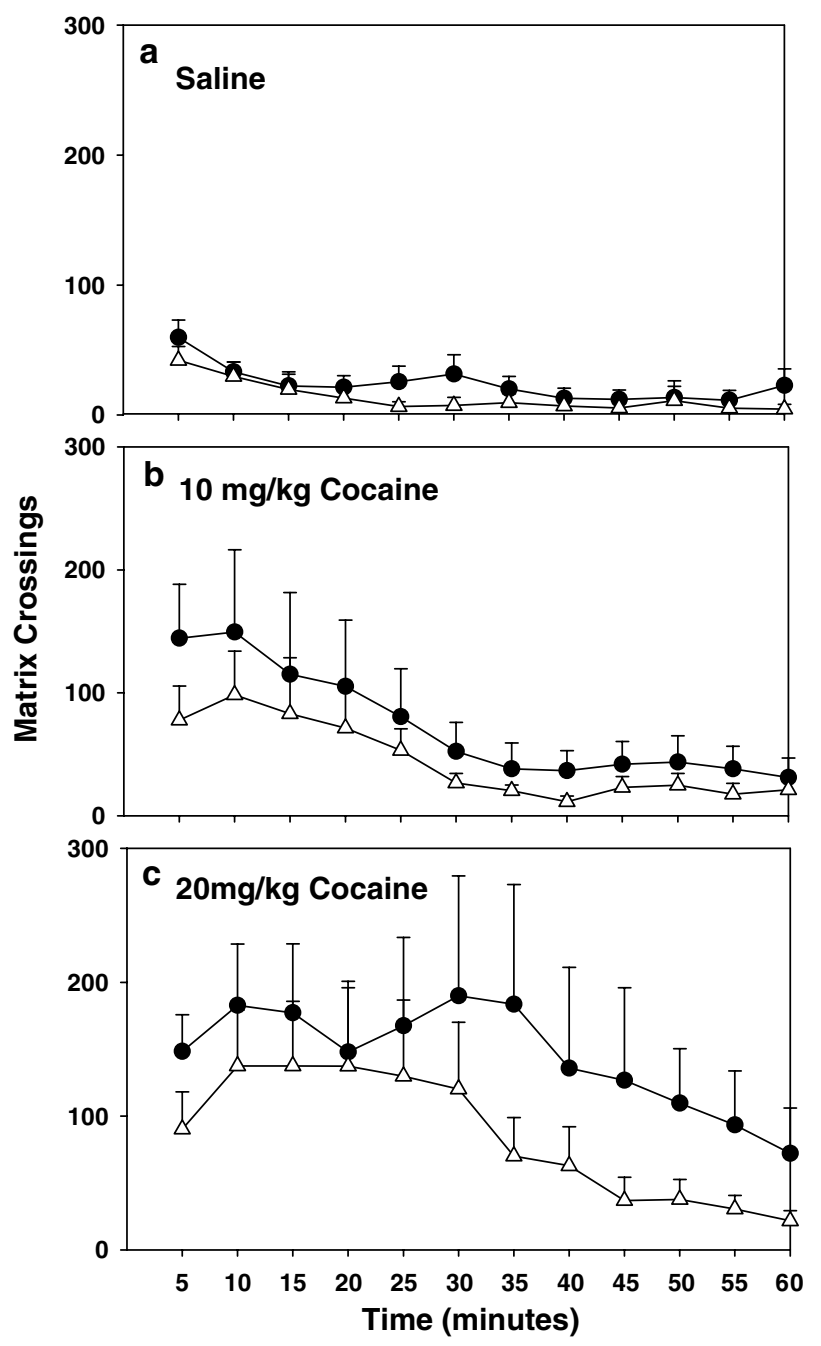

Figure I Number of matrix crossings in 5 min intervals over I h test by periadolescent (open triangles) and adult (closed circles) rats administered I ml/ $\mathrm{kg}$ saline vehicle (a), $10 \mathrm{mg} / \mathrm{kg}$ cocaine (b), or $20 \mathrm{mg} / \mathrm{kg}$ cocaine (c). Rats were habituated to the test cage for $30 \mathrm{~min}$ before injection at time 0 . Points represent means \pm SEM $(n=7-10)$. Periadolescent rats exhibited fewer crossings than adults in the $30-60$ min period, regardless of drug dose. 
main effects of dose $(\mathrm{F}(2,45)=8.69, p<0.001)$ and time $(\mathrm{F}(5,225)=2.76, p<0.05)$, a significant dose $\times$ time interaction $(\mathrm{F}(10,225)=2.59, p<0.01)$, but no main effect of age, nor a significant three-way interaction. Three-way ANOVA on the second $30 \mathrm{~min}$ post-cocaine interval $(30-60 \mathrm{~min}$ post-cocaine) revealed significant main effects of age $(\mathrm{F}(1,45)=4.72, p<0.05)$, dose $(\mathrm{F}(2,45)=6.92, p<0.001)$, time $(\mathrm{F}(5,225)=4.07, p<0.01)$, a significant dose $\times$ time interaction $(\mathrm{F}(10,225)=3.56, p<0.001)$, but no significant threeway interaction. All groups habituated similarly to the test environment for $30 \mathrm{~min}$ before injection (data not shown).

After repeated cocaine injections, matrix crossings increased in an age- and dose-specific manner (Figure 2a-c). A three-way ANOVA revealed a significant age $\times$ dose $\times$ day interaction $(\mathrm{F}(6,108)=5.49, p<0.001)$ as well as significant main effects of dose $(\mathrm{F}(2,36)=25.92, p<0.001)$ and days $(\mathrm{F}(3,108)=9.69, p<0.001)$. Subsequent two- and one-way ANOVAs and post hoc comparisons revealed specific effects. First, at the $10 \mathrm{mg} / \mathrm{kg}$ cocaine dose, adult rats showed significantly more matrix crossings on day 15 than day 0 $(p<0.05$, one-way ANOVA on days $(\mathrm{F}(3,18)=4.144$, $p<0.02)$ ). In contrast, no significant sensitization occurred among periadolescents at this dose. However, at the $20 \mathrm{mg} /$ $\mathrm{kg}$ dose, adults failed to show sensitized responding, whereas periadolescents showed more matrix crossings on days 10 and 15 compared with day $0(p<0.02$, one-way ANOVA on days $(F(3,21)=8.47, p<0.001))$. Second, age comparisons on specific test days indicated that adult rats exhibited significantly more matrix crossings than periadolescents under three conditions: day 10 (third injection) of $10 \mathrm{mg} / \mathrm{kg}$ cocaine, day 15 (fourth injection) of $10 \mathrm{mg} / \mathrm{kg}$ cocaine, and day 5 (second injection) of $20 \mathrm{mg} / \mathrm{kg}$ cocaine. Finally, adult rat responses to $20 \mathrm{mg} / \mathrm{kg}$ cocaine on day 10 were surprisingly low; given that we did not record motor stereotypies on day 10, we cannot rule out the possibility that stereotyped behavior interfered with matrix crossings.

Stereotyped behaviors. Observations of motor stereotypies demonstrated that acute cocaine injection dose-dependently increased some of the observed behaviors (data not shown). Sniffing was increased by cocaine; a two-way age $\times$ dose ANOVA revealed a significant main effect of dose $(\mathrm{F}(2,45)=5.96, p<0.01)$, with follow-up one-way ANOVA and $t$-tests with Bonferroni's correction indicating significant differences between 0 and $20 \mathrm{mg} / \mathrm{kg}$ doses. Neither the main effect of age nor an age $\times$ dose interaction was significant.

With regard to acute effects of cocaine on grooming, a significant age $\times$ dose interaction $(\mathrm{F}(2,45)=3.18, p=0.05)$ followed by one-way ANOVA and $t$-tests with Bonferroni's correction indicated differences among periadolescents such that grooming was increased in a dose-dependent manner between 0 and 10 or $20 \mathrm{mg} / \mathrm{kg}$ doses. Main effects of age and dose were not significant, although a trend toward significant main effect of dose $(F(2,45)=2.89, p=0.06)$ suggests increased grooming induced by cocaine, regardless of age group.

With regard to observed rearing behavior, no significant effects of acute cocaine were observed, although a trend toward main effect of dose $(\mathrm{F}(2,45)=2.74, p=0.08)$ suggests increased rearing by cocaine, regardless of age group. These results together reveal behavior-specific effects of cocaine on motor stereotypies in periadolescent and adult male rats alike.

After repeated cocaine injections, observed motor stereotypies did not reveal robust sensitization (data not shown). Three-way ANOVAs with age $\times$ dose $\times$ days (repeated measure) as factors on sniffing, grooming, or rearing did not reveal significant interactions. With regard to sniffing, a significant main effect of dose $(\mathrm{F}(2,40)=7.85, p<0.001)$ with follow-up testing showed that $20 \mathrm{mg} / \mathrm{kg}$ cocaine elevated sniffing regardless of age group or test day. With regard to grooming, a trend toward main effect of days $(\mathrm{F}(1,37)=3.89$, $p=0.06$ ) suggested a decline on day 15 compared with day 0 , regardless of age or dose group. Also a main effect of age on grooming $(\mathrm{F}(1,37)=4.38, p<0.05)$ revealed significantly more grooming behavior by periadolescents over adults, regardless of cocaine dose or test day. With regard to rearing, the main effect of dose $(\mathrm{F}(2,37)=10.68, p<0.001)$ with follow-up testing indicated increased rearing induced by $20 \mathrm{mg} / \mathrm{kg}$ cocaine compared with saline or $10 \mathrm{mg} / \mathrm{kg}$ cocaine, regardless of age group or test day.

\section{Experiment II: Acquisition of Cocaine Self-Administration}

Individual Fisher's exact tests conducted on the difference in proportions of rats acquiring self-administration on each day of testing revealed no difference between age groups in rate of acquisition of cocaine self-administration (Figure 3 and Table 1). Moreover, active lever pressing

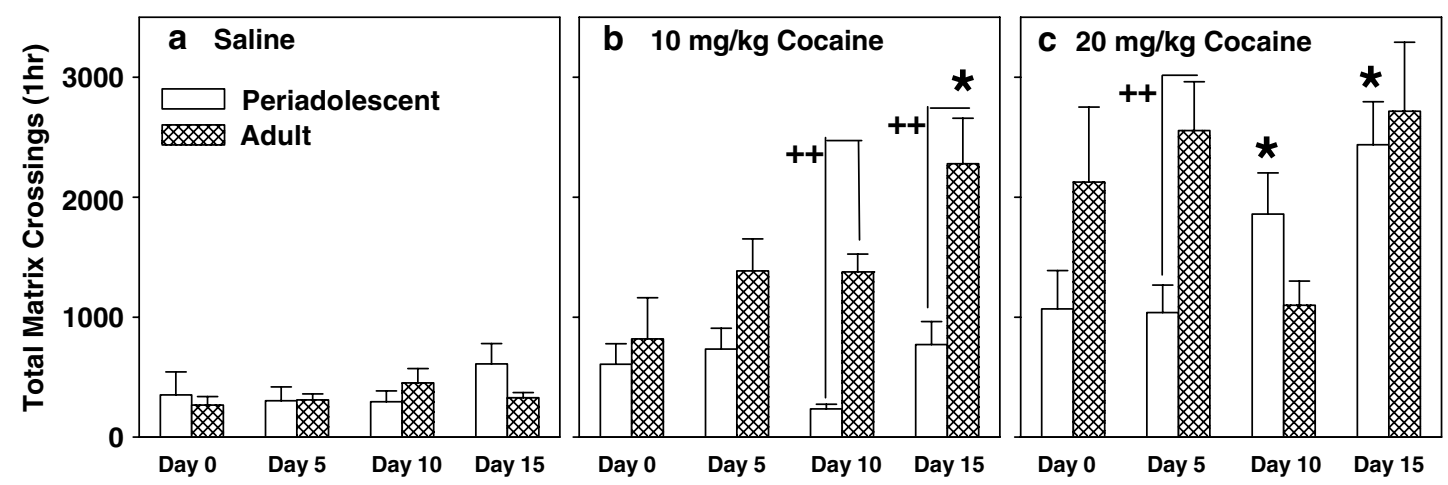

Figure 2 Total matrix crossings in repeated $2 \mathrm{~h}$ test sessions in periadolescent (open bars) or adult rats (hatched bars) administered saline vehicle (I ml/ $\mathrm{kg} ; \mathrm{a}$ ), $10 \mathrm{mg} / \mathrm{kg}$ cocaine (b), or $20 \mathrm{mg} / \mathrm{kg}$ cocaine (c) on days 0, 5, 10, and 15. Rats were habituated for 30 min before each injection. Bars represent means \pm SEM $(n=6-8)$. Significant differences from age- and dose-matched day 0 groups are indicated $(*<<0.05)$, as well as significant differences between age groups $\left({ }^{++} p<0.0 \mathrm{l}\right)$. 


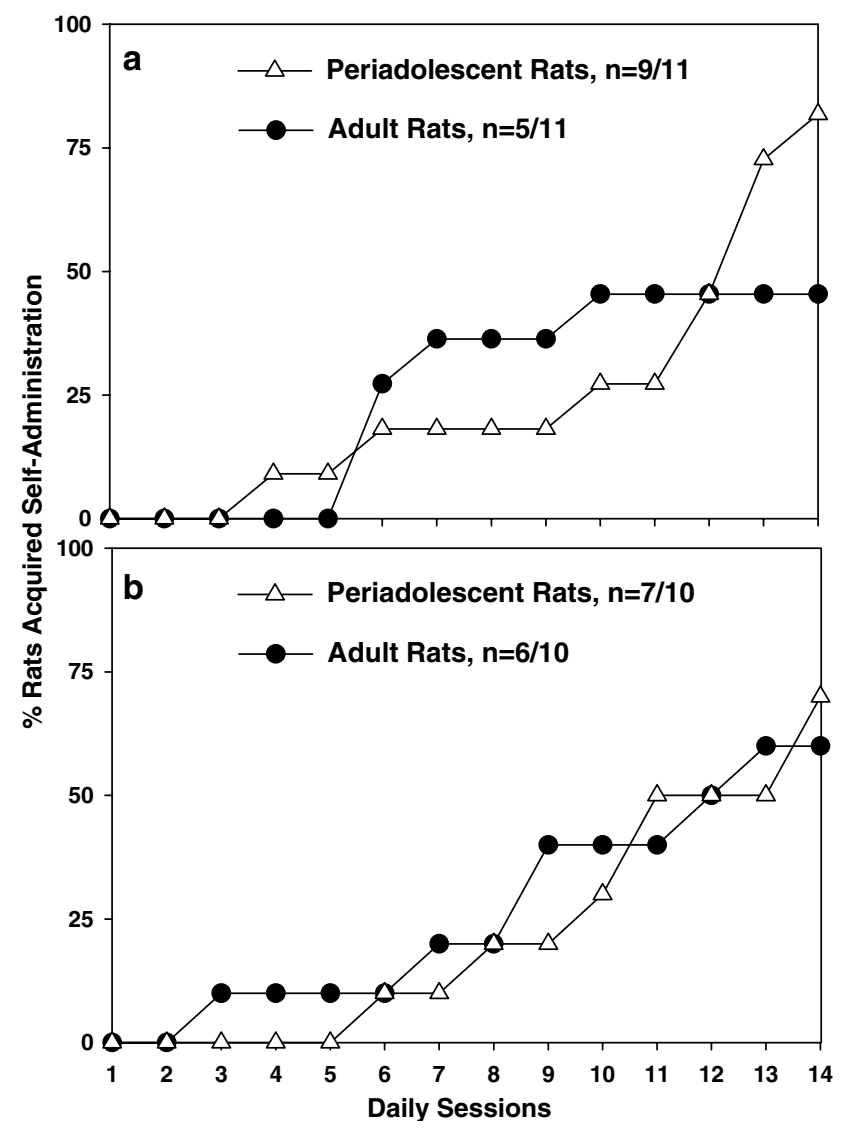

Figure 3 Percent of rats acquiring self-administration of a low dose of cocaine $(0.37 \mathrm{mg} / \mathrm{kg} /$ infusion; $n=11$ per age group (a)) or high dose ( $0.74 \mathrm{mg} / \mathrm{kg} /$ infusion; $n=10$ per age groups) across daily test sessions in periadolescent (open triangles) or adult (closed circles) rats. Final proportions on day 14 are indicated in legends. (See Materials and methods for definition of acquisition.) did not differ between age groups (Figure $4 \mathrm{a}$ and $\mathrm{b}$ ). To analyze active and inactive lever pressing separately at each dose, we conducted two-way ANOVAs with days (repeated measure) $\times$ age as factors (results in Table 2). For both cocaine doses, main effects of days on active lever-presses showed increased responding across acquisition. At the low dose, a main effect of days on inactive leverpresses revealed decreased responding over days. Interestingly, a main effect of age on inactive lever-presses in the low-dose cocaine group revealed higher inactive lever pressing by periadolescent over adult rats, regardless of test day. Total cocaine intake $(\mathrm{mg} / \mathrm{kg})$ across the 14 -day acquisition test did not differ across dose or age groups (Table 3).

Catheter surgery and cocaine self-administration did not impede weight gain in adolescent or adult rats, compared with age-matched, drug-naïve control rats from another experiment. Among the present rats that acquired selfadministration (with highest cocaine intake), initial average body weights were $143.8 \pm 3.1$ and $338.0 \pm 3.4 \mathrm{~g}$ for periadolescent $(n=16)$ and adult rats $(n=11)$, respectively, and final body weights on the last day of self-administration were $236.3 \pm 4.4$ and $397.0 \pm 6.1 \mathrm{~g}$. For matched controls, initial body weights were $147.5 \pm 3.6$ and $372.4 \pm 5.9 \mathrm{~g}$ for periadolescent $(n=11)$ and adult $(n=15)$ groups, respectively, and final body weights were $237.0 \pm 4.5$ and $413.5 \pm 6.9$ g. (Values are mean \pm SEM.)

\section{Experiment III: Basal and Cocaine-Stimulated Dopamine Levels in the Nucleus Accumbens}

As revealed by no net flux methodology, neither basal extracellular levels of dopamine nor in vivo recovery of dopamine differed across age groups (Figure 5). Estimated extracellular dopamine concentrations (nM) were

Table I Results of Fisher's Exact Test for a $2 \times 2$ Contingency Table on the Difference in Proportions of Rats Acquiring Self-Administration over 14 Days Acquisition Testing

\begin{tabular}{|c|c|c|c|c|c|c|}
\hline \multirow[b]{2}{*}{ Day } & \multicolumn{3}{|c|}{$0.37 \mathrm{mg} / \mathrm{kg} /$ infusion cocaine } & \multicolumn{3}{|c|}{$0.74 \mathrm{mg} / \mathrm{kg} /$ infusion cocaine } \\
\hline & $\begin{array}{l}\text { Periadolescent, } \\
\text { acquired (out of II) }\end{array}$ & $\begin{array}{l}\text { Adult, acquired } \\
\text { (out of II) }\end{array}$ & p-value & $\begin{array}{l}\text { Periadolescent, } \\
\text { acquired (out of 10) }\end{array}$ & $\begin{array}{l}\text { Adult, acquired } \\
\text { (out of } 10)\end{array}$ & $p$-value \\
\hline । & 0 & 0 & $>0.9999$ & 0 & 0 & $>0.9999$ \\
\hline 2 & 0 & 0 & $>0.9999$ & 0 & 0 & $>0.9999$ \\
\hline 5 & । & 0 & $>0.9999$ & 0 & । & $>0.9999$ \\
\hline 6 & 2 & 3 & $>0.9999$ & । & । & $>0.9999$ \\
\hline 7 & 2 & 4 & 0.6531 & । & 2 & $>0.9999$ \\
\hline 8 & 2 & 4 & 0.6531 & 2 & 2 & $>0.9999$ \\
\hline 9 & 2 & 4 & 0.6531 & 2 & 4 & 0.6285 \\
\hline 13 & 8 & 5 & 0.3870 & 5 & 6 & $>0.9999$ \\
\hline 14 & 9 & 5 & 0.1827 & 7 & 6 & $>0.9999$ \\
\hline
\end{tabular}


$5.39 \pm 1.03(n=9)$ and $4.77 \pm 0.66(n=8)$ for periadolescent and adult rats, respectively $(\mathrm{T}(15)=-0.52)$. The slopes of the no net flux regression lines, used to estimate in vivo probe recovery, were $0.55 \pm 0.08$ and $0.71 \pm 0.05$ for periadolescent and adult rats, respectively $(\mathrm{T}(15)=1.59)$.

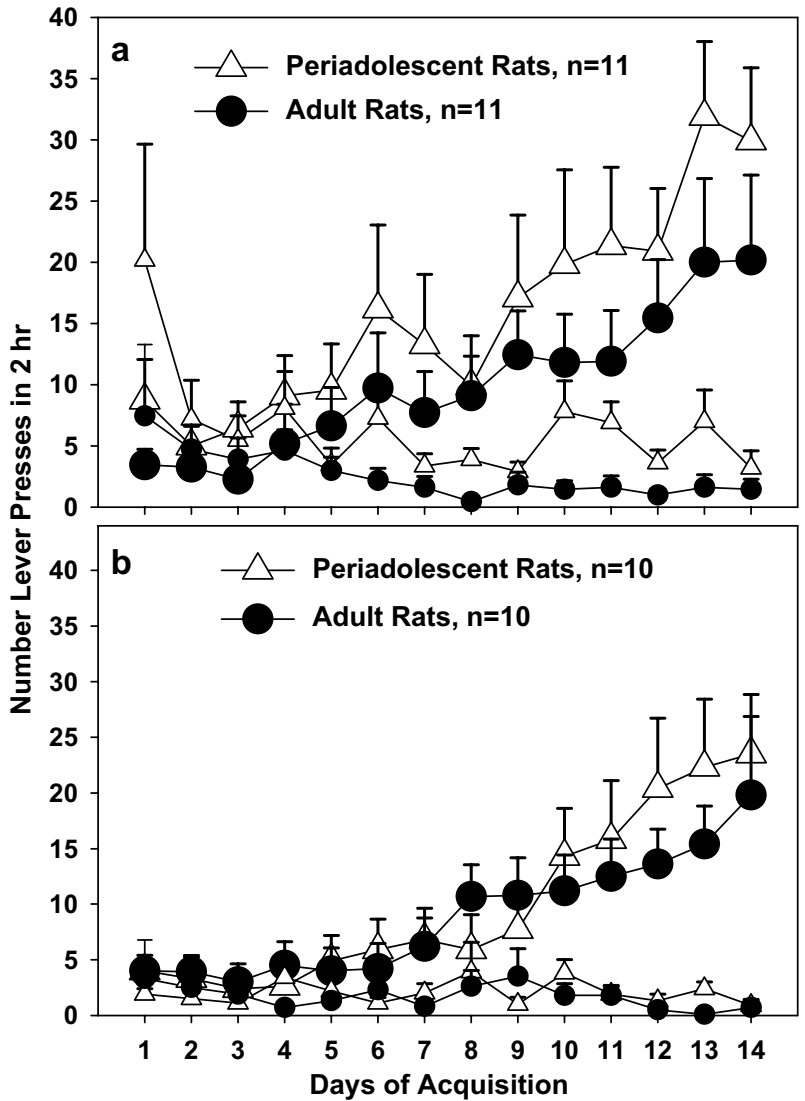

Figure 4 Number of presses on the active lever (large symbols) or inactive lever (small symbols) during cocaine self-administration in periadolescent (open triangles) and adult rats (closed circles) with access to a low-dose cocaine $(0.37 \mathrm{mg} / \mathrm{kg} /$ infusion (a)) or high-dose $(0.74 \mathrm{mg} / \mathrm{kg} /$ infusion (b)). Points represent means $\pm \operatorname{SEM}(n=|0-| \mid)$.
In the same rats, i.v. cocaine dose-dependently increased dopamine in the nucleus accumbens to a similar degree in periadolescent and adult rats (Figure 6a). Baseline dialysate dopamine was similar between ages $(6.20 \pm 0.90$ and $7.13 \pm 1.33 \mathrm{nM}$ for periadolescent and adult rats, respectively; values not adjusted for probe efficiency), so data were analyzed as a percentage of baseline. A significant main effect of time $(F(26,416)=30.39, p<0.0001)$ and simple effects analyses specified increases in dopamine for 10, 20, or $30 \mathrm{~min}$ after the low, mid-, or high dose, respectively. Neither the main effect of age $(F(1,16)=0.025)$ nor the age $\times$ time interaction $(\mathrm{F}(26,416)=1.30)$ was significant.

I.v. cocaine produced higher brain cocaine in adults than periadolescents, after the mid-range and high-dose injections (Figure 6b). A trend toward a main effect of age did not reach significance $(\mathrm{F}(1,7)=4.84, p=0.06)$, but the main effect of time $(F(20,140)=67.39, p<0.0001)$ and the age $\times$ time interaction were significant $(\mathrm{F}(20,140)=3.50$, $p<0.0001)$. Follow-up analyses revealed greater brain cocaine in adults for $20 \mathrm{~min}$ after the 0.74 and $2.92 \mathrm{mg} / \mathrm{kg}$ i.v. injections.

I.p. cocaine increased dopamine similarly across ages (Figure 7a). Baseline dopamine did not differ (1.99 and $2.24 \mathrm{nM}$ for periadolescents and adults, respectively), so data were analyzed as a percentage of baseline. Neither the main effect of age $(\mathrm{F}(1,11)=0.002, p=0.96)$ nor the age $\times$ time interaction $(\mathrm{F}(17,187)=0.48, p=0.96)$ was significant, although the main effect of time was significant $(\mathrm{F}(17,187)=20.96, p<0.0001)$; cocaine increased dopamine for $40 \mathrm{~min}$ post-injection.

Table 3 Cocaine Intake $(\mathrm{mg} / \mathrm{kg})$

\begin{tabular}{lcc}
\hline & Periadolescent & Adult \\
\hline $0.37 \mathrm{mg} / \mathrm{kg} /$ infusion cocaine & $82.72 \pm 24.39(n=1 \mathrm{I})$ & $46.35 \pm 13.00(n=1 \mathrm{l})$ \\
$\mathrm{T}(\mathrm{I} 6)=-1.32, p=0.21$ & & \\
$0.74 \mathrm{mg} / \mathrm{kg} /$ infusion cocaine & $|1| .56 \pm 23.79(n=10)$ & $81.73 \pm 23.26(n=10)$ \\
$\mathrm{T}(\mathrm{|} 8)=-0.29, p=0.98$ & & \\
\hline
\end{tabular}

Table 2 Results of Two-Way ANOVAs (Days (Repeated Measure) $\times$ Age) on Lever Pressing on the Active Lever (Left Columns) or Inactive Lever (Right Columns) over 14 Days Acquisition Testing in Periadolescent vs Adult Rats

\begin{tabular}{|c|c|c|c|c|c|c|c|}
\hline \multicolumn{4}{|c|}{ Active lever } & \multicolumn{4}{|c|}{ Inactive lever } \\
\hline Effect & df & $\mathbf{F}$ & $p$ & Effect & df & $\mathbf{F}$ & $p$ \\
\hline Days & 13,260 & 12.57 & $<\left.0.000\right|^{*}$ & Days & 13,260 & 3.76 & $<0.000$ I* \\
\hline Age & I, 20 & 1.25 & 0.28 & Age & 1,20 & 5.43 & $0.030 *$ \\
\hline \multicolumn{8}{|l|}{ High dose } \\
\hline Days & 13,234 & 16.11 & $<\left.0.000\right|^{*}$ & Days & 13,234 & 1.24 & 0.25 \\
\hline Age & 1,18 & 0.093 & 0.76 & Age & I, 18 & 0.12 & 0.74 \\
\hline Days $\times$ age & 13,234 & 1.16 & 0.31 & Days $\times$ age & 13,234 & $|.5|$ & 0.12 \\
\hline
\end{tabular}

* indicates $p<0.05$ 


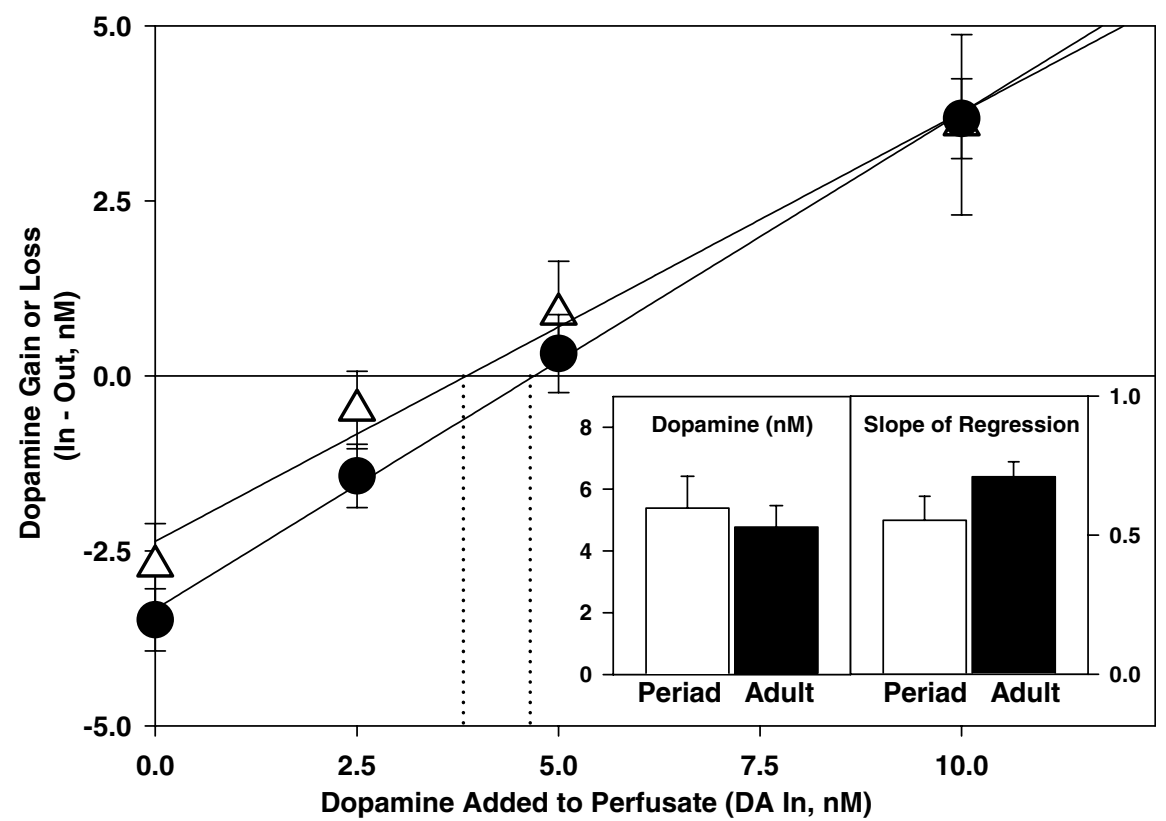

Figure 5 Dopamine gain or loss to the brain as a function of perfusate concentration for periadolescent (open triangles, $n=9$ ) or adult (closed circles, $n=8$ ) rats. The point of no net flux (zero on the $y$-axis) is the estimated extracellular concentration of dopamine. The left panel of inset graphs indicates average estimated dopamine concentrations based on individual regression functions for periadolescent (open bar) and adult (filled bar) rats. The right panel shows average slope of individual regression lines, an indicator of in vivo dopamine clearance.

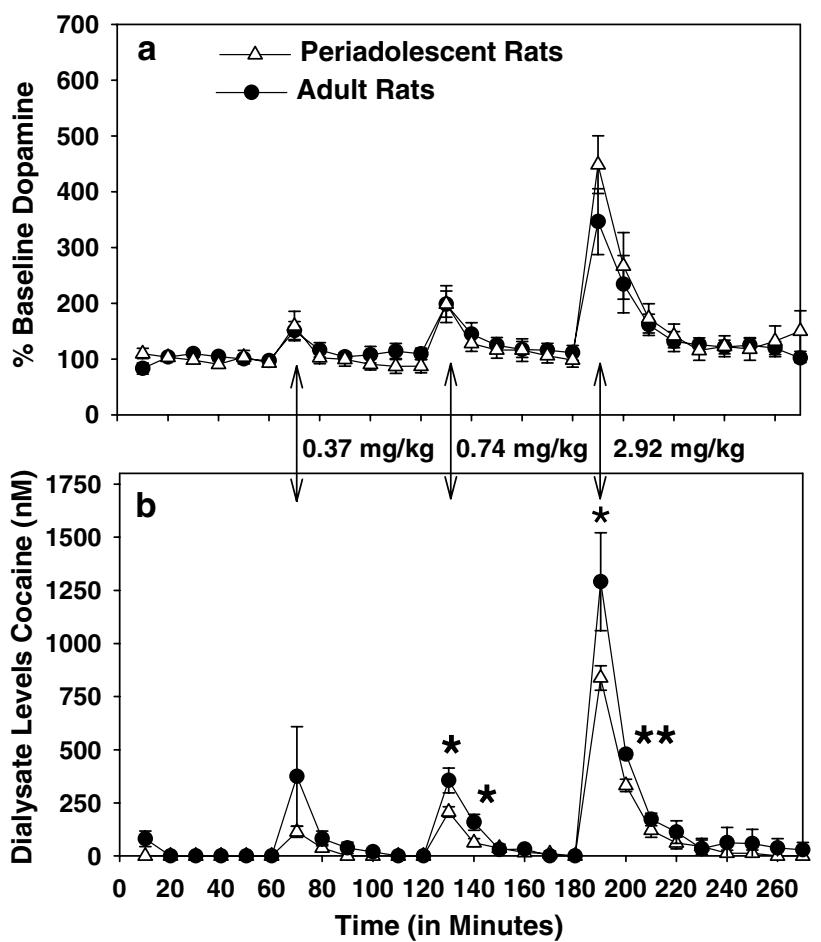

Figure 6 Percent basal dopamine concentrations ((a), $n=8-10)$ and dialysate levels of cocaine ((b), $n=4-5)$ in 10 min intervals for periadolescent (open triangles) or adult (closed circles) rats at baseline or following i.v. injection of approximately $0.37,0.74$, or $2.92 \mathrm{mg} / \mathrm{kg}$ cocaine. Significant differences between age groups are indicated ${ }^{*} p<0.05$, *** $p<0.0$ I)

I.p. cocaine injections also produced similar brain cocaine across ages (Figure $7 \mathrm{~b}$ ). The main effect of age was not significant $(F(1,9)=1.068)$ nor was age $\times$ time interaction $(\mathrm{F}(11,99)=0.32, p=0.98)$. A significant main effect of time $(\mathrm{F}(11,99)=52.24, p<0.0001)$ and a follow-up test revealed significant increases in brain cocaine for 70 min post-injection.

\section{DISCUSSION}

The present results are in partial agreement with previous reports of periadolescent hyposensitivity to i.p. cocaineinduced motor activity compared with younger or older rats. Nevertheless, extracellular levels of dopamine in the nucleus accumbens were similar across age groups under basal conditions and after acute i.p. cocaine injection, suggesting that age differences in locomotor stimulant effects are not mediated by dopamine efflux in the nucleus accumbens. Age-related differences in cocaine-induced locomotor behavior were not paralleled by rate of acquisition of i.v. cocaine self-administration, nor by differences in the amount of cocaine self-administered. Furthermore, extracellular levels of dopamine in the nucleus accumbens stimulated by i.v. cocaine were similar across age groups. Together, these findings present a developmental dissociation between the locomotor and reinforcing effects of cocaine; periadolescent rats displayed lower sensitivity to the locomotor effects of the drug, but similar sensitivity to the reinforcing effects of the drug.

A lower sensitivity of periadolescent rats to the acute motor stimulatory effects of cocaine was previously manifest in behaviors such as matrix crossings (Snyder et al, 1998; Spear and Brick, 1979), rearing (Laviola et al, 1995), stereotyped sniffing (Laviola et al, 1995; Spear and Brick, 1979), and head-scanning (Laviola et al, 1995). In the present experiment, matrix crossings were lower in periadolescent compared with adult rats during the second 


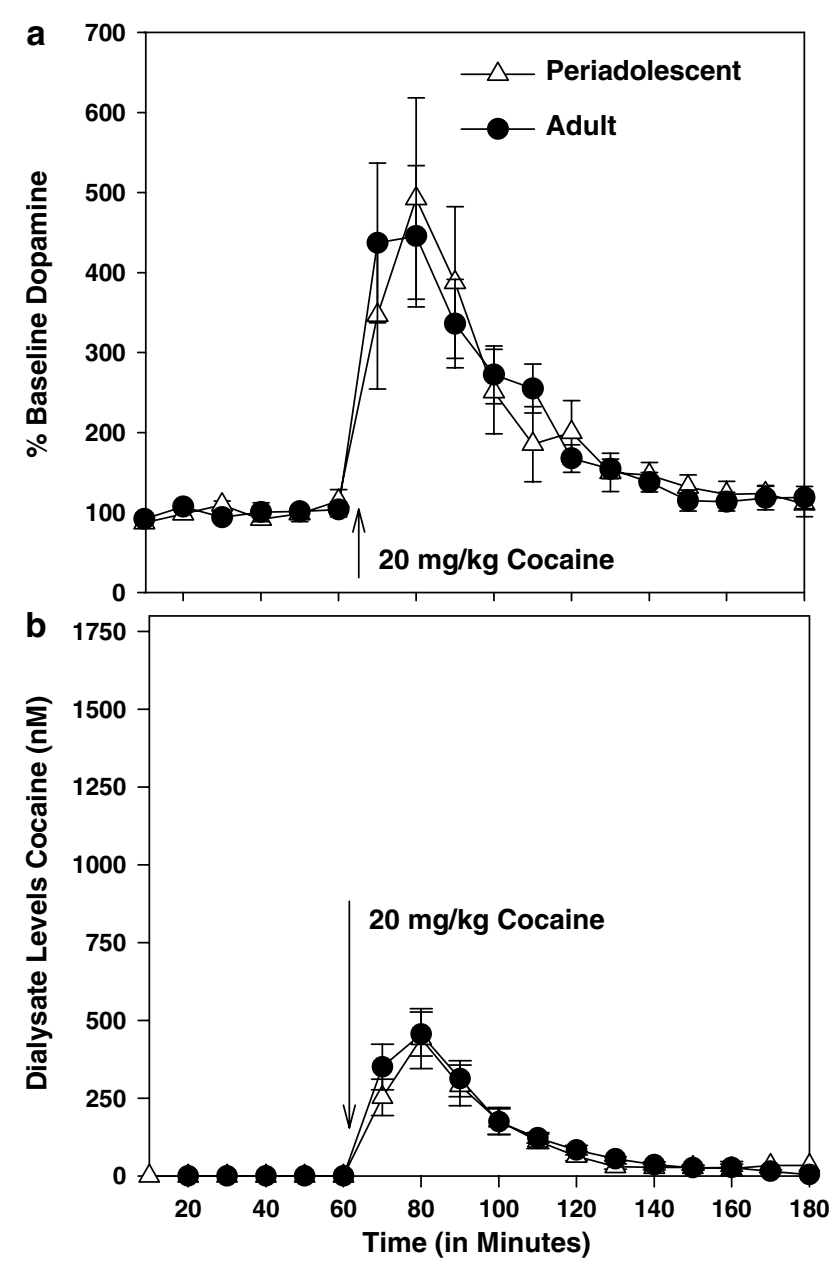

Figure 7 Percent basal dopamine concentrations ((a), $n=5-8)$ and dialysate levels of cocaine ((b), $n=5-6)$ in 10 min intervals for periadolescent (open triangles) or adult (closed circles) rats at baseline or following i.p. injection of $20 \mathrm{mg} / \mathrm{kg}$ cocaine.

30 min interval after acute injection, regardless of drug dose, but motor stereotypies were mainly similar across age groups, with only grooming showing evidence of higher rates among periadolescents $v s$ adults. These data support recent assertions that periadolescent hyposensitivity to dopaminergic compounds is detectable but less robust than previously postulated (Maldonado and Kirstein, 2005b). Strain differences could also explain the less robust hyposensitivity presently observed in Wistar rats $v s$ that previously seen with Sprague-Dawley rats. Also our subjects were handled and weighed for several days before experimentation, which may have elevated responding in periadolescents to near adult levels; experimenter handling before cocaine injections increased cocaine-induced locomotion in periadolescent but not adult rats (Maldonado and Kirstein, 2005a, b).

In previous studies, a lower sensitivity of periadolescent rats to the motor effects of cocaine extended to a lesser degree of motor sensitization after repeated cocaine injections (Collins and Izenwasser, 2002; Laviola et al, 1995; Snyder et al, 1998). In the present extended dosing regimen, locomotion by periadolescents failed to sensitize after repeated administration of $10 \mathrm{mg} / \mathrm{kg}$ cocaine, when adult locomotion sensitized. Also periadolescents exhibited less motor activity than adults after the third and fourth $10 \mathrm{mg} / \mathrm{kg}$ injections and after the second injection of $20 \mathrm{mg} /$ $\mathrm{kg}$ cocaine. However, periadolescents did eventually show locomotor sensitization after the third and fourth $20 \mathrm{mg} / \mathrm{kg}$ cocaine injections. Neither periadolescent nor adult rats showed sensitization of motor stereotypies, perhaps again owing to differences in strain and dosing schedule.

Behavioral and neurochemical sensitization have been linked to vulnerability to drug reinforcement (Robinson and Berridge, 2000). Thus, periadolescent hyposensitivity to locomotor sensitization predicts hyposensitivity to cocainerelated behavioral reinforcement, but this prediction was not supported in the present experiments. Although more periadolescent rats in the low-dose cocaine condition tended to acquire self-administration compared to adults, the difference in proportions was not significant and therefore periadolescent and adult rats demonstrated the same rate of acquisition. Furthermore, active lever pressing and cocaine intake were similar across age groups for the doses of cocaine tested. A separate analysis was conducted to evaluate the influence of cocaine concentration, infusion volume, and infusion duration on operant behavior in both age groups and demonstrated that these factors did not change the observation of no age-related difference in the acquisition or maintenance of cocaine self-administration (data not shown). In another study, cocaine intake over a short 5-day nose-poke acquisition test did not differ significantly between PND 27, 37, and 90 rats (Belluzzi et al, 2005). Also cocaine- or morphine-conditioned place preference was indistinguishable between periadolescent and adult Sprague-Dawley rats (Campbell et al, 2000). Although we cannot rule out the possibility that lower cocaine doses might demonstrate significant age-related differences in reward and reinforcement paradigms, these data sets imply that although cocaine-related motor activity and behavioral reinforcement (or reward) share neural circuitry, they are not inextricably linked.

Notably, periadolescent rats in the present low cocaine dose group pressed the inactive lever significantly more than their adult counterparts. High inactive lever pressing may represent impulsivity or low stimulus control among periadolescents, an idea consistent with hypothesized immature systems for behavioral suppression in adolescent subjects (Adriani and Laviola, 2003; Laviola et al, 2003).

The principal action of cocaine is to block monoamine reuptake (Kuhar et al, 1991). Although other transporters and brain regions are involved (Bardo, 1998, for review), blockade of dopamine transporters in the nucleus accumbens appears necessary for cocaine's acute and chronic effects (Church and Justice, 1987; Hurd and Ungerstedt, 1989; Kelly et al, 1975; Koob, 1992; White, 1998; Wise and Bozarth, 1987). Consistent with the present results on behavioral reinforcement but not locomotion, periadolescent and adult rats exhibited similar nucleus accumbens basal and cocaine-stimulated dopamine levels. These results suggest that dopamine transporter expression and function are likewise similar across age groups. Accordingly, insofar as the slope of the no-net-flux line of regression reflects in vivo uptake (Parsons and Justice, 1994), no differences in dopamine clearance by uptake mechanisms such as transporters were demonstrated in our experiments. In 
corroboration, similar basal expression of dopamine transporters was reported for dorsal and ventral striatum of periadolescent and adult Sprague-Dawley rats (Collins and Izenwasser, 2002). On the other hand, repeated i.p. cocaine injection increased dopamine transporter expression in adult Sprague-Dawley rats but not periadolescents (Collins and Izenwasser, 2002), providing a potential explanation for sensitization in adult but not periadolescent rats at our mid-range cocaine dose. Age differences in acute motor effects of cocaine are left unexplained.

One caveat in the present neurochemical analysis must be considered: a distinction between core and shell subregions of the nucleus accumbens is not reported. Dopaminergic activity in the core of the nucleus accumbens is closely aligned with motor activity and instrumental learning (Kelley et al, 1997; Kelley and Swanson, 1997; MaldonadoIrizarry and Kelley, 1994; Pulvirenti et al, 1994), whereas dopamine in the shell appears responsive to primary rewards (Carlezon and Wise, 1996; Di Chiara et al, 1993; Tanda et al, 1997). Based on our behavioral results, the core but not shell is predicted to show age-related differences in extracellular dopamine after i.p. cocaine.

Postsynaptic to dopamine terminals, GABAergic neurons in the striatum integrate dopamine signals in part via complex interactions between D1- and D2-like dopamine receptors (Fontana et al, 1993; Hu and White, 1997; Ikemoto et al, 1997). Thus, transient overexpression of D1 and D2 dopamine receptors during periadolescence (eg Teicher et al, 1995) and altered receptor coupling with cAMP (Andersen, 2002) may regulate responsiveness to cocaine. Moreover, projections between the frontal cortex, midbrain, and nucleus accumbens modulate the effects of acute and repeated cocaine (Vanderschuren and Kalivas, 2000, for review), and these regions mature just before or during periadolescence (Alexander and Goldman, 1978; Insel et al, 1990; Kalsbeek et al, 1988; Teicher et al, 1998, 1991). On the molecular level, age-specific sensitivity of transcription factors to drug exposure may have extensive and enduring effects on neural signaling. For example, periadolescent male CD-1 mice showed higher deltaFosB upregulation in the nucleus accumbens than adults after repeated cocaine or amphetamine injections (Ehrlich et al, 2002). Future experiments will define roles for these cellular and molecular pathways in mediating developmental changes in cocaine responsivity.

Pharmacokinetic mechanisms are not likely to mediate periadolescent-specific behavioral effects of psychostimulants. Despite evidence for periadolescent motor hyposensitivity to stimulants (Adriani and Laviola, 2000; Bolanos et al, 1998; Infurna and Spear, 1979; Spear and Brake, 1983, 1979), systemic amphetamine injections produced a monotonic rise in post-mortem amphetamine brain concentrations across ontogeny that did not correlate with the developmental trajectory of behavioral responding (Spear and Brake, 1983). In other experiments, age-specific effects of dopaminergic ligands were maintained across systemic and intracerebral routes of administration, implying pharmacodynamic rather than pharmacokinetic mechanisms (Campbell et al, 1988; Frantz and Van Hartesveldt, 1995). Our data showed no age difference in dialysate cocaine after i.p. cocaine injections. Although we did observe lower dialysate cocaine levels in periadolescent $v s$ adult rats after a high-dose i.v. cocaine injection, behavioral reinforcement mediated by i.v. cocaine did not differ across age groups.

Overall, a developmental dissociation between cocainestimulated locomotor activity and reinforced behavior may be practical from an ethological perspective. In periadolescence, mature reinforcement circuitry used to assign hedonic value to stimuli may be necessary for survival. On the other hand, continued flexibility in motor reactivity throughout adolescence may facilitate relocation from the early home environment to a new territory. Furthermore, even if reinforcement circuitry is not fully mature by periadolescence, its direct activation with a stimulus as strong as i.v. cocaine may not provide an assay sensitive enough to detect age-related qualitative differences in reinforcement processing. In contrast, motor activation by doses of cocaine over the present extended dosing regimen appears to be sensitive to developmental changes.

Although extrapolation from rodent to human psychopharmacology may be tenuous, the present data suggest that human adolescents experience the same vulnerability to cocaine reinforcement, and thereby cocaine dependence, as adults. Compounded by altered responsivity to stress, immature rational decision-making skills, high noveltyseeking, and social factors leading to drug experimentation such as increased free time, cash flow, and independence, human adolescents may be particularly vulnerable to initiating an addiction cycle with cocaine or other psychomotor stimulant drugs (Gruber, 2001; Laviola et al, 2003; Spear, 2000; Steinberg, 1999).

\section{ACKNOWLEDGEMENTS}

We thank David Stouffer for his excellent technical assistance and Mike Arends for editorial assistance. This is publication number 15044-NP from The Scripps Research Institute. This work was supported by US Public Health Service Grants DA11004 (LHP), DA05950-02 (KJF) DA 08467.

\section{REFERENCES}

Adriani W, Chiarotti F, Laviola G (1998). Elevated novelty seeking and peculiar $d$-amphetamine sensitization in periadolescent mice compared with adult mice. Behav Neurosci 112: 1152-1166.

Adriani W, Granstrem O, Macri S, Izykenova G, Dambinova S, Laviola G (2004). Behavioral and neurochemical vulnerability during adolescence in mice: studies with nicotine. Neuropsychopharmacology 29: 869-878.

Adriani W, Laviola G (2000). A unique hormonal and behavioral hyporesponsivity to both forced novelty and $d$-amphetamine in periadolescent mice. Neuropharmacology 39: 334-346.

Adriani W, Laviola G (2003). Elevated levels of impulsivity and reduced place conditioning with $d$-amphetamine: two behavioral features of adolescence in mice. Behav Neurosci 117: 695-703.

Adriani W, Macri S, Pacifici R, Laviola G (2002). Peculiar vulnerability to nicotine oral self-administration in mice during early adolescence. Neuropsychopharmacology 27: 212-224.

Alexander GE, Goldman PS (1978). Functional development of the dorsolateral prefrontal cortex: an analysis utilizing reversible cryogenic depression. Brain Res 143: 233-249.

Andersen SL (2002). Changes in the second messenger cyclic AMP during development may underlie motoric symptoms in 
attention deficit/hyperactivity disorder (ADHD). Behav Brain Res 130: 197-201.

Bardo MT (1998). Neuropharmacological mechanisms of drug reward: beyond dopamine in the nucleus accumbens. Crit Rev Neurobiol 12: 37-67.

Bauer RH, Duncan DL (1975). Differential effects of $d$-amphetamine in mature and immature rats. Physiol Psychol 3: 312-316.

Belluzzi JD, Wang R, Leslie FM (2005). Acetaldehyde enhances acquisition of nicotine self-administration in adolescent rats. Neuropsychopharmacology 30: 705-712.

Bolanos CA, Glatt SJ, Jackson D (1998). Subsensitivity to dopaminergic drugs in periadolescent rats: a behavioral and neurochemical analysis. Brain Res Dev Brain Res 111: 25-33.

Bronstein PM (1972). Open field behavior of the rat as a function of age. J Comp Physiol Psychol 80: 335-341.

Bronstein PM (1979). The stimulus control of locomotor persistence in rat pups. In: Spear NE, Campbell BA (eds). Ontogeny of Learning and Memory. Lawrence Erlbaum Associates: Hillsdale, NJ. pp 57-66.

Brown S (1990). Peer groups. In: Feldman SS, Elliott GR (eds). At the Threshold: The Developing Adolescent. Harvard University Press: Cambridge, MA. pp 171-196.

Burns LH, Annett L, Kelley AE, Everitt BJ, Robbins TW (1996). Effects of lesions to amygdala, ventral subiculum, medial prefrontal cortex, and nucleus accumbens on the reaction to novelty: implication for limbic-striatal interactions. Behav Neurosci 110: 60-73.

Caine SB, Lintz R, Koob GF (1993). Intravenous drug selfadministration techniques in animals. In: Sahgal A (ed). Behavioural Neuroscience: A Practical Approach. Oxford University Press: New York. pp 117-143.

Campbell A, Baldessarini RJ, Teicher MH (1988). Decreasing sensitivity to neuroleptic agents in developing rats: evidence for a pharmacodynamic factor. Psychopharmacology 94: 46-51.

Campbell JO, Wood RD, Spear LP (2000). Cocaine and morphineinduced place conditioning in adolescent and adult rats. Physiol Behav 68: 487-493.

Carlezon Jr WA, Wise RA (1996). Rewarding actions of phencyclidine and related drugs in nucleus accumbens shell and frontal cortex. J Neurosci 16: 3112-3122.

Caza PA, Spear LP (1980). Ontogenesis of morphine-induced behavior in the rat. Pharmacol Biochem Behav 13: 45-50.

Church WH, Justice Jr JB (1987). Rapid sampling and determination of extracellular dopamine in vivo. Anal Chem 59: 712-716.

Collins SL, Izenwasser S (2002). Cocaine differentially alters behavior and neurochemistry in periadolescent versus adult rats. Brain Res Dev Brain Res 138: 27-34.

Collins SL, Izenwasser S (2004). Chronic nicotine differentially alters cocaine-induced locomotor activity in adolescent $v s$ adult male and female rats. Neuropharmacology 46: 349-362.

Critchley H, Daly E, Phillips M, Brammer M, Bullmore E, Williams $S$ et al (2000). Explicit and implicit neural mechanisms for processing of social information from facial expressions: a functional magnetic resonance imaging study. Hum Brain Mapp 9: 93-105.

Di Chiara G, Tanda G, Frau R, Carboni E (1993). On the preferential release of dopamine in the nucleus accumbens by amphetamine: further evidence obtained by vertically implanted concentric dialysis probes. Psychopharmacology 112: 398-402.

Donny EC, Caggiula AR, Mielke MM, Jacobs KS, Rose C, Sved AF (1998). Acquisition of nicotine self-administration in rats: the effects of dose, feeding schedule, and drug contingency. Psychopharmacology (Berlin) 136: 83-90.

Ehrlich ME, Sommer J, Canas E, Unterwald EM (2002). Periadolescent mice show enhanced DeltaFosB upregulation in response to cocaine and amphetamine. J Neurosci 22: 9155-9159.
Elliott BM, Faraday MM, Phillips JM, Grunberg NE (2005). Adolescent and adult female rats differ in sensitivity to nicotine's activity effects. Pharmacol Biochem Behav 80: 567-575.

Emmett-Oglesby MW, Lane JD (1992). Tolerance to the reinforcing effects of cocaine. Behav Pharmacol 3: 193-200.

Estroff TW, Schwartz RH, Hoffmann NG (1989). Adolescent cocaine abuse. Addictive potential, behavioral and psychiatric effects. Clin Pediatr (Phila) 28: 550-555.

Faraday MM, Elliott BM, Phillips JM, Grunberg NE (2003). Adolescent and adult male rats differ in sensitivity to nicotine's activity effects. Pharmacol Biochem Behav 74: 917-931.

Fontana D, Post RM, Weiss SR, Pert A (1993). The role of D1 and D2 dopamine receptors in the acquisition and expression of cocaine-induced conditioned increases in locomotor behavior. Behav Pharmacol 4: 375-387.

Frantz K, Van Hartesveldt C (1999). Locomotion elicited by MK801 in developing and adult rats: temporal, environmental, and gender effects. Eur J Pharmacol 369: 145-157.

Frantz KJ, Van Hartesveldt C (1995). Locomotor effecs of quinpirole in the nucleus accumbens of developing rat pups. Soc Neurosci Abstr 21: 280.

Gelbard HA, Teicher MH, Faedda G, Baldessarini RJ (1989). Postnatal development of dopamine D1 and D2 receptor sites in rat striatum. Brain Res Dev Brain Res 49: 123-130.

Gruber J (2001). Risky Behavior among Youths: An Economic Analysis. University of Chicago Press: Chicago.

Hooks MS, Duffy P, Striplin C, Kalivas PW (1994). Behavioral and neurochemical sensitization following cocaine self-administration. Psychopharmacology (Berlin) 115: 265-272.

Hu XT, White FJ (1997). Dopamine enhances glutamate-induced excitation of rat striatal neurons by cooperative activation of D1 and D2 class receptors. Neurosci Lett 224: 61-65.

Hurd YL, Ungerstedt U (1989). Influence of a carrier transport process on in vivo release and metabolism of dopamine: dependence on extracellular $\mathrm{Na}^{+}$. Life Sci 45: 283-293.

Ikemoto S, Glazier BS, Murphy JM, McBride WJ (1997). Role of dopamine D1 and D2 receptors in the nucleus accumbens in mediating reward. J Neurosci 17: 8580-8587.

Insel TR, Miller LP, Gelhard RE (1990). The ontogeny of excitatory amino acid receptors in rat forebrain-I. $N$-Methyl- $D$-aspartate and quisqualate receptors. Neuroscience 35: 31-43.

Infurna RN, Spear LP (1979). Developmental changes in amphetamine-induced taste aversions. Pharmacol Biochem Behav 11: 31-35.

Johanson CE, Fischman MW (1989). The pharmacology of cocaine related to its abuse. Pharmacol Rev 41: 3-52.

Kalsbeek A, Voorn P, Buijs RM, Pool CW, Uylings HB (1988). Development of the dopaminergic innervation in the prefrontal cortex of the rat. J Comp Neurol 269: 58-72.

Kandel DB, Davies M (1992). Progression to regular marijuana involvement: phenomenology and risk factors for near-daily use. In: Glantz MD, Pickens RW (eds). Vulnerability to Drug Abuse. American Psychological Association Press: Washington, DC. pp 211-253.

Kelley AE, Smith-Roe SL, Holahan MR (1997). Responsereinforcement learning is dependent on $N$-methyl-D-aspartate receptor activation in the nucleus accumbens core. Proc Natl Acad Sci USA 94: 12174-12179.

Kelley AE, Swanson CJ (1997). Feeding induced by blockade of AMPA and kainate receptors within the ventral striatum: a microinfusion mapping study. Behav Brain Res 89: 107-113.

Kelly PH, Seviour PW, Iversen SD (1975). Amphetamine and apomorphine responses in the rat following 6-OHDA lesions of the nucleus accumbens septi and corpus striatum. Brain Res 94: 507-522.

Koob GF (1992). Drugs of abuse: anatomy, pharmacology and function of reward pathways. Trends Pharmacol Sci 13: 177-184. 
Koob GF, Rassnick S, Heinrichs S, Weiss F (1994). Alcohol, the reward system and dependence. Exs 71: 103-114.

Kuhar MJ, Ritz MC, Boja JW (1991). The dopamine hypothesis of the reinforcing properties of cocaine. Trends Neurosci 14: 299-302.

Lanier LP, Isaacson RL (1977). Early developmental changes in the locomotor response to amphetamine and their relation to hippocampal function. Brain Res 126: 567-575.

Laviola G, Adriani W, Terranova ML, Gerra G (1999). Psychobiological risk factors for vulnerability to psychostimulants in human adolescents and animal models. Neurosci Biobehav Rev 23: 993-1010.

Laviola G, Dell'Omo G, Chiarotti F, Bignami G (1994). dAmphetamine conditioned place preference in developing mice: relations with changes in activity and stereotypies. Behav Neurosci 108: 514-524.

Laviola G, Macri S, Morley-Fletcher S, Adriani W (2003). Risk-taking behavior in adolescent mice: psychobiological determinants and early epigenetic influence. Neurosci Biobehav Rev 27: 19-31.

Laviola G, Pascucci T, Pieretti S (2001). Striatal dopamine sensitization to $\mathrm{D}$-amphetamine in periadolescent but not in adult rats. Pharmacol Biochem Behav 68: 115-124.

Laviola G, Wood RD, Kuhn C, Francis R, Spear LP (1995). Cocaine sensitization in periadolescent and adult rats. J Pharmacol Exp Ther 275: 345-357.

Levin ED, Rezvani AH, Montoya D, Rose JE, Swartzwelder HS (2003). Adolescent-onset nicotine self-administration modeled in female rats. Psychopharmacology 169: 141-149.

Lonnroth P, Jansson PA, Smith U (1987). A microdialysis method allowing characterization of intercellular water space in humans. Am J Physiol 253: E228-E231.

Maldonado AM, Kirstein CL (2005a). Cocaine-induced locomotor activity is increased by prior handling in adolescent but not adult female rats. Physiol Behav 86: 568-572.

Maldonado AM, Kirstein CL (2005b). Handling alters cocaineinduced activity in adolescent but not adult male rats. Physiol Behav 84: 321-326.

Maldonado-Irizarry CS, Kelley AE (1994). Differential behavioral effects following microinjection of an NMDA antagonist into nucleus accumbens subregions. Psychopharmacology (Berlin) 116: 65-72.

O'Dell LE, Khroyan TV, Neisewander JL (1996). Dose-dependent characterization of the rewarding and stimulant properties of cocaine following intraperitoneal and intravenous administration in rats. Psychopharmacology (Berlin) 123: 144-153.

Panskepp J (1981). The ontogeny of play in rats. Dev Psychobiol 14: 327-332.

Parsons LH, Justice Jr JB (1992). Extracellular concentration and in vivo recovery of dopamine in the nucleus accumbens using microdialysis. J Neurochem 58: 212-218.

Parsons LH, Justice Jr JB (1994). Quantitative approaches to in vivo brain microdialysis. Crit Rev Neurobiol 8: 189-220.

Parsons LH, Smith AD, Justice JB (1991). The in vivo microdialysis recovery of dopamine is altered independently of basal level by 6-hydroxydopamine lesions to the nucleus accumbens. J Neurosci Methods 40: 139-147.

Pulvirenti L, Berrier R, Kreifeldt M, Koob GF (1994). Modulation of locomotor activity by NMDA receptors in the nucleus accumbens core and shell regions of the rat. Brain Res 664: 231-236.

Robinson TE, Berridge KC (2000). The psychology and neurobiology of addiction: an incentive-sensitization view. Addiction 95(Suppl 2): S91-S117.

Russell VA (2000). The nucleus accumbens motor-limbic interface of the spontaneously hypertensive rat as studied in vitro by the superfusion slice technique. Neurosci Biobehav Rev 24: 133-136.

SAMHSA (2003). Substance Abuse and Mental Health Services Administration, Results from the 2002 National Survey on Drug
Use and Health: National Findings. Office of Applied Studies: Rockville, MD.

Schochet TL, Kelley AE, Landry CF (2004). Differential behavioral effects of nicotine exposure in adolescent and adult rats. Psychopharmacology (Berlin) 175: 265-273.

Seeman P, Bzowej NH, Guan HC, Bergeron C, Becker LE, Reynolds GP et al (1987). Human brain dopamine receptors in children and aging adults. Synapse 1: 399-404.

Shalaby IA, Spear LP (1980). Chronic administration of haloperidol during development: later psychopharmacological responses to apomorphine and arecoline. Pharmacol Biochem Behav 13: 685-690.

Snyder KJ, Katovic NM, Spear LP (1998). Longevity of the expression of behavioral sensitization to cocaine in preweanling rats. Pharmacol Biochem Behav 60: 909-914.

Spear LP (2000). The adolescent brain and age-related behavioral manifestations. Neurosci Biobehav Rev 24: 417-463.

Spear LP, Brake SC (1983). Periadolescence: age-dependent behavior and psychopharmacological responsivity in rats. Dev Psychobiol 16: 83-109.

Spear LP, Brick J (1979). Cocaine-induced behavior in the developing rat. Behav Neural Biol 26: 401-415.

Stamford JA (1989). Development and ageing of the rat nigrostriatal dopamine system studied with fast cyclic voltammetry. J Neurochem 52: 1582-1589.

Steinberg L (1999). Adolescence, 5th edn. McGraw-Hill College: Boston. 519pp.

Tanda G, Pontieri FE, Di Chiara G (1997). Cannabinoid and heroin activation of mesolimbic dopamine transmission by a common mul opioid receptor mechanism. Science 276: 2048-2050.

Tarazi FI, Tomasini EC, Baldessarini RJ (1998). Postnatal development of dopamine D4-like receptors in rat forebrain regions: comparison with D2-like receptors. Brain Res Dev Brain Res 110: 227-233.

Tarazi FI, Tomasini EC, Baldessarini RJ (1999). Postnatal development of dopamine D1-like receptors in rat cortical and striatolimbic brain regions: an autoradiographic study. Dev Neurosci 21: 43-49.

Teicher MH, Dumont NL, Andersen SL (1998). The developing prefrontal cortex: is there a transient interneuron state stimulates catecholamine terminals? Synapse 29: 89-91.

Teicher MH, Gallitano AL, Gelbard HA, Evans HK, Marsh ER, Booth RG et al (1991). Dopamine D1 autoreceptor function: possible expression in developing rat prefrontal cortex and striatum. Brain Res Dev Brain Res 63: 229-235.

Teicher MH, Andersen SL, Hostetter Jr JC (1995). Evidence for dopamine receptor pruning between adolescence and adulthood in striatum but not nucleus accumbens. Brain Res Dev Brain Res 89: 167-172.

Vanderschuren LJ, Kalivas PW (2000). Alterations in dopaminergic and glutamatergic transmission in the induction and expression of behavioral sensitization: a critical review of preclinical studies. Psychopharmacology (Berl) 151: 99-120.

Vastola BJ, Douglas LA, Varlinskaya EI, Spear LP (2002). Nicotineinduced conditioned place preference in adolescent and adult rats. Physiol Behav 77: 107-114.

White FJ (1998). Cocaine and the serotonin saga. Nature 393: 118-119.

Wise RA (1996). Neurobiology of addiction. Curr Opin Neurobiol 6: $243-251$.

Wise RA, Bozarth MA (1987). A psychomotor stimulant theory of addiction. Psychol Rev 94: 469-492.

Zuckerman M (1992). Sensation-seeking: the balance between risk and reward. In: Lipsitt LP, Mitnick LL (eds). Self-Regulatory Behavior and Risk Taking: Causes and Consequences. Ablex Publishing: Norwood, NJ. pp 129-182. 